Mesopotamia J. of Agric.

Vol. (42) No.(1) 2014
ISSN: 2224-9796 (Online)

ISSN: $1815-316 \mathrm{X}$ (Print)

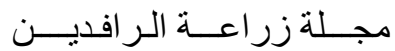

المجلا(42) العدد(1) 2014

\title{
EFFECT OF THE NEW FARMING SYSTEM-ZERO TILLAGE IN GROWTH,YIELD AND ITS COMPONENTS OF BREAD WHEAT ,DURUM WHEAT AND BARLEY CROPS IN MODERATE RAINFALL AREA IN NINEVAH PROVINCE.
}

Abdulsattar A. Alrijabo

Field Crop Dept. College of Agric \& Forestry Mosul University/Iraq

Email: dr_alrijabo@yahoo.com

\begin{abstract}
A field study was conducted under three different environmental sites within the region introduced for the first time in Iraq through the import of new ZT seeder. The study implemented in 2006-2007 season compared with conventional agriculture and sowing after chisel plow. It was applied on numerous varieties belonging to the three field crops Bread Wheat, Durum Wheat and Barley.

The grain yield results showed that the ZT planting method was equal with farmer planting method (conventional tillage) in all locations and crops studied while chisel planting method was the superior in this trait, this result is encouraging for the adoption of this new technology because the input in a ZT doesn't need cultivation, while in other studied traits results showed that the chisel method excelled in 15 traits, while the ZT method excelled in 9 traits and the farmer methods in 4 traits only, this results strengthens the recommendation to adopt the ZT planting method for its limited implementation cost compared with the rest of the planting methods. In the same time grain yield in ZT planting method was not less than conventional tillage (con.) in any way.
\end{abstract}

Received : 22/3/2012 Accepted: 10 /9/2012

\section{INTRODUCTION}

Farming system in Moderate Rainfall Area in Ninevah :In this region Barley crop is grown by more than $60 \%$ of the total area and the rest of the area planted with Bread Wheat, in cultivation of Wheat farmers used crop disc plow seeder and they used relatively modern seeders, such as Rama and Kaspardo but their numbers are limited in these areas as its technology is not completed, in Barley cultivation farmers used disc plow seeder only. Crop rotations in this region are barley barley, wheat - wheat, wheat - barley- wheat and wheat - lentil - wheat , and wheat - fallow - wheat. In the application of Wheat - fallow - Wheat rotation , after harvesting the Wheat crop the farmers leave their fields without planting for a full season, but they plow their fields as the fallowing: winter plowing, spring plowing for weed control and in Autumn the farmer plow his field as Autumns plowing to soften the soil and create seed bed, then he will sows his field before the first effective rain fall. In the seasonally sowing, after harvesting the crop, the farmer waits for the first effective rain because he need it for germination of weed seeds, so he will wait for at least two weeks after rainfall to ensure germination of weed seeds and then plow the field to eliminate the developing weed seedling, after this plowing he will sow crop seeds with the same disc plow seeder. Conservation agriculture (CA) is as minimal soil disturbance (no-till) and permanent soil cover (mulch) combined with rotations, is a more sustainable cultivation system for the future than those presently practiced.(Hobbs, 2007). No-till is sowing a crop 
without prior cultivation and with very little soil disturbance at seeding. All soils can be no-tilled! In sandy soils, no-till with stubble retention minimizes wind erosion and where it leaves furrows, makes water harvesting easier in water repellent soils. In clay and loamy soils, no-till minimizes run-off and erosion by water and improves soil structure. By controlling weeds, which are hosts to diseases, problems with both weeds and diseases are reduced. However, the year before seeding good stubble management is also essential.(Ross et.al,1998) . However, experimental evidence is beginning to emerge after some years of stubble retention that soil properties and grain yield have increased compared with annual burning of stubbles. (Anderson et.al,2005). In no-till farming, as the name implies, tillage for seedbed preparation and weed control is avoided entirely. Some growers in California and elsewhere state that in no-tilled fields, they see less runoff and better water infiltration (Pettygrove et.al,1995). The soil cover helps to create a more stable environment and the organic matter serves as 'fodder" for the soil biota. (Kurt S. ,2002). The most efficient tillage system in reducing surface runoff and soil losses was no tillage. In the conventionally tilled treatment (CT) soil losses were greater than in any of the no tillage treatments.( Engela,2009). In an experimental field in the Transvolcanic Belt of Mexico for 14 years. After 14 years of continuous practice, it was found that zero tillage with residue retention is a feasible management technology for farmers producing maize and wheat in the agroecological zone studied, resulting in a better soil quality and higher yields than with the conventional farmer practice (maize monoculture, conventional tillage and residue removal).(Mariela,2009).In a nation-wide project, conventional tillage was compared with reduced tillage. The results indicated that obviously the effects of tillage methods differed over the regions, but in practically all situations, reduced tillage methods (chisel plowing) showed promising results. No significant yield reductions were found when compared to the traditional tillage methods (moldboard plowing). The field capacity using a chisel plow increased from 0.50 to $0.75 \mathrm{ha} \mathrm{h}-1$. On the other hand, no-tillage methods did not produce favorable results, indicating that some degree of soil disturbance is necessary. Conservation tillage by chisel plowing can be recommended in most provinces of Iran but care must be taken that the sowing operation is done correctly.( Arzhang et.al ,2009)

\section{MATERIALS AND METHODS}

The researches program in 2006-07 were planned to compare crop performance under three crop establishment techniques (farmer method, chisel cultivation, zero-tillage) with several cultivars of major crops Bread wheat(Cham $/ 6$ and AboGraib/3) and Durum Wheat(OmRabia/5 and Karonia) and Barley(Rihan/3 and Jazeera/1) at 3 locations under Moderate Rainfall Area.(Table A and B).

Experimental treatments (zero-tillage, chisel cultivation) were compared with the conventional planting method of the farmer, it is worth mentioning that the farmer (control treatment ) was supplied with the same varieties seeds. Seeding rate was $120 \mathrm{~kg} /$ Hectare for Bread Wheat and Barley, $140 \mathrm{~kg} /$ Hectare for Durum Wheat .

The experimental design for this factorial experiment was RCBD with 3 replicates, the factors are locations (3),planting methods(3), crop cultivars (2 for each crop), the experimental unit equal 0.25 Hectare. Duncan Test was used for testing significantly between data results. The following traits were studied: Plant height $(\mathrm{cm})$ : mean of the height of 10 plants for each experimental unit .Straw biomass 
(gm/m2): mean of weight of straw for each experimental unit .Spikes/m2: mean of spikes/m2 for each experimental unit . Grains /spike: mean number of grains for 10 spikes from each experimental unit. Weight of 1000 grains (gm):mean of grain weight of 1000 grains from each experimental unit .Specific weight ( $\mathrm{kg} /$ hectoliter): mean of specific weight for each experimental unit. Weight of grain $(\mathrm{gm} / \mathrm{m} 2)$ : mean of grain yield for each experimental unit. Grain yield (kg/hectare):grain yield after harvesting the total area(one Hectare) and measuring actual weight of grain, this trait without replicate, so it is without analysis.

Note : For additional cultivars Tellaffer/ 3 (Telkief Location) \& Cham/ 5 (Bashyqa Location) they are out of analyses, but we involved farm grain yield results in Figures to compare grain yields only, the sowing rate and sowing date are the same with other cultivars in location. The final goal of the program is to encourage farmers to adopt these technologies in order to improve their production.

Table (A) : Crop varieties and planting methods.

\begin{tabular}{|c|c|c|c|c|c|c|}
\hline Crops & $\begin{array}{l}\text { Planting } \\
\text { methods }\end{array}$ & $\begin{array}{c}\text { Sowing } \\
\text { date }\end{array}$ & $\begin{array}{l}\text { Planting } \\
\text { methods }\end{array}$ & $\begin{array}{c}\text { Sowing } \\
\text { date }\end{array}$ & $\begin{array}{l}\text { Planting } \\
\text { methods }\end{array}$ & $\begin{array}{c}\text { Sowing } \\
\text { date }\end{array}$ \\
\hline \multirow{3}{*}{$\begin{array}{l}\text { Durum } \\
\text { Wheat }\end{array}$} & Chisel & $17 / 1 / 2007$ & Chisel & $19 / 1 / 2007$ & Chisel & $18 / 1 / 2007$ \\
\hline & Z.T & $16 / 1 / 2007$ & Z.T & $21 / 1 / 2007$ & Z.T & $18 / 1 / 2007$ \\
\hline & $\begin{array}{l}\text { Farmer } \\
\text { Method }\end{array}$ & $17 / 1 / 2007$ & $\begin{array}{l}\text { Farmer } \\
\text { Method }\end{array}$ & $21 / 1 / 2007$ & $\begin{array}{l}\text { Farmer } \\
\text { Method }\end{array}$ & $18 / 1 / 2007$ \\
\hline \multirow{3}{*}{$\begin{array}{c}\text { Bread } \\
\text { Wheat }\end{array}$} & Chisel & $17 / 1 / 2007$ & Chisel & $20 / 1 / 2007$ & Chisel & $18 / 1 / 2007$ \\
\hline & Z.T & $16 / 1 / 2007$ & Z.T & $21 / 1 / 2007$ & Z.T & $18 / 1 / 2007$ \\
\hline & $\begin{array}{l}\text { Farmer } \\
\text { Method }\end{array}$ & $17 / 1 / 2007$ & $\begin{array}{l}\text { Farmer } \\
\text { Method }\end{array}$ & $21 / 1 / 2007$ & $\begin{array}{l}\text { Farmer } \\
\text { Method }\end{array}$ & $18 / 1 / 2007$ \\
\hline \multirow{3}{*}{ Barley } & Chisel & $17 / 1 / 2007$ & Chisel & $19 / 1 / 2007$ & Chisel & $19 / 1 / 2007$ \\
\hline & Z.T & $16 / 1 / 2007$ & Z.T & $21 / 1 / 2007$ & Z.T & $19 / 1 / 2007$ \\
\hline & $\begin{array}{l}\text { Farmer } \\
\text { Method }\end{array}$ & $17 / 1 / 2007$ & $\begin{array}{l}\text { Farmer } \\
\text { Method }\end{array}$ & $19 / 1 / 2007$ & $\begin{array}{l}\text { Farmer } \\
\text { Method }\end{array}$ & $19 / 1 / 2007$ \\
\hline
\end{tabular}

Table(B): Annual rainfall and soil texture of the 3 locations.

\begin{tabular}{|c|c|c|c|c|c|c|}
\hline Location & $\begin{array}{c}\text { Annual } \\
\text { rainfall }(\mathrm{mm})\end{array}$ & $\begin{array}{c}\text { Clay }+ \\
\text { Silt } \%\end{array}$ & $\begin{array}{c}\text { Clay } \\
\%\end{array}$ & $\begin{array}{c}\text { Silt } \\
\%\end{array}$ & $\begin{array}{c}\text { Sand } \\
\%\end{array}$ & Soil texture \\
\hline Bashyqa & 193 & 54.7 & 16.2 & 38.5 & 45.3 & Sandy loam \\
\hline Telkief & 337 & 67.1 & 35.0 & 31.1 & 33.0 & Clay loam \\
\hline AL-Hamdania & 386 & 54.0 & 22.5 & 31.5 & 46.1 & Loam \\
\hline
\end{tabular}


Mesopotamia J. of Agric.

Vol. (42) No.(1) 2014
ISSN: 2224-9796 (Online) ISSN: $1815-316 \mathrm{X}$ (Print)

$$
\text { مجــلـة زر اعـــة الر افديــن } 2014
$$
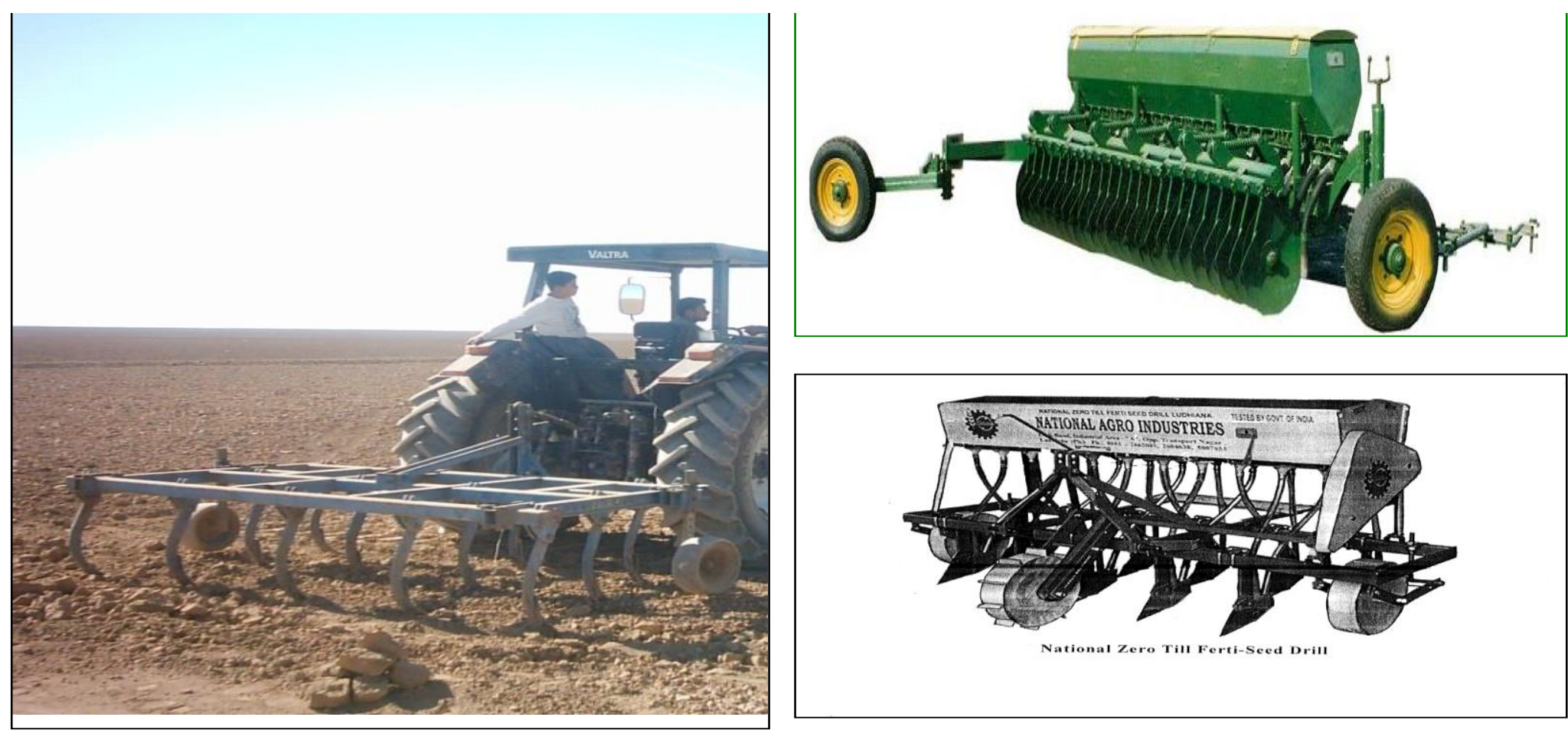

Nationat Zero Till Ferti-Seed Drill

Fig(1): Upper right figure ;disc plow , Lower right figure ; ZT seeder , Left figure ; Chisel. 


\section{RESULTS AND DISCUSSION}

A-1-Effect of planting methods on Grains yield $(\mathrm{gm} / \mathrm{m} 2)$ of Bread Wheat:As shown in table (1) the best significant results of grains yield $(\mathrm{gm} / \mathrm{m} 2)$ in factors and interaction are summarized $:(\mathrm{P})=$ Chisel, $(\mathrm{C})=$ Cham $/ 6,(\mathrm{~L})=$ Tell Kief , $(\mathrm{L} \times \mathrm{C})=\mathrm{Cham} / 6$ in Tell kief,$(\mathrm{L} \times \mathrm{P})=$ Chisel then Z.T in Tell Kief , $(\mathrm{C} \times \mathrm{P})=\mathrm{Cham} / 6$ under Chisel , (L X C XP) $=$ Cham $/ 6$ under Chisel in Tell Kief.

B-1-Effect of planting methods on Grains yield $(\mathrm{gm} / \mathrm{m} 2)$ of Durum Wheat: As shows in Table (2) the best results of this trait in factors and interactions are summarized :( P ) = Chisel , ( C ) = OM Rabia and Karonia ( N. S. ), ( L ) = Tell kief , $(\mathrm{L} \times \mathrm{C})=$ Karonia in Tell kief,$(\mathrm{L} \times \mathrm{P})=$ Chisel in Tell kief. , $(\mathrm{C} \times \mathrm{P})=$ Karonia under Chisel , $(\mathrm{L} \times \mathrm{C} \times \mathrm{P})=$ Karonia under Chisel then $\mathrm{Z}$.T . in Tell kief .

C-1- Effect of planting methods on Grains yield ( $\mathrm{gm} / \mathrm{m} 2)$ of Barley: As shown in Table (3) the best results of this trait in factors and interactions are summarized:( $\mathrm{P})=$ Chisel , $(\mathrm{C})=$ Rihan $/ 3,(\mathrm{~L})=$ Tellkief,$(\mathrm{L} \times \mathrm{C})=$ Rihan in Tellkief,$(\mathrm{L} \times \mathrm{P})=$ Chisel in Tellkief, $(\mathrm{C} \times \mathrm{P})=$ Rihan under Z.T then Chisel, $(\mathrm{L} \times \mathrm{C} \times \mathrm{P})=$ Rihan under Chisel then Z.T and Con. In Tellkief.

Note: the grains yield traits below for Wheat and barley are out of analyses because there are no replicates, it is the result of actual field yield under the interaction of the 3 factors too, so we involved there result in figures to compare numbers only.

A-2-Grains yield (Kg/hectare) trait in Bread Wheat:_As shown in Fig (2) the best result of grains yield is $(1480 \mathrm{Kg} / \mathrm{hec}$.)in $\mathrm{Cham} / 6$ under Chisel planting method.

B-2 -Grains yield (Kg/hectare) trait in Durum Wheat: As shown in Fig (3) the best results of grains yield is $(1360 \mathrm{~kg} / \mathrm{hec}$.) in Karonia under Z .T . planting method in Tell kief location .

C-2- Grains yield (Kg/hectare) trait in Barley: As shown in Fig. (4) the best results of Grains Yield is $(1320 \mathrm{~kg} / \mathrm{hectar})$ in Rihan $/ 3$ under Z.T. (1260Kg/hectar) under Chisel planting method in Tellkief location .

A-3-No.of Spikes / $\mathbf{m} \mathbf{2}$ in Bread Wheat: The best significant result of No. of spikes $/ \mathrm{m} 2$ in factors and interaction are summarized:(P)=Chisel $,(\mathrm{C})=\mathrm{Cham} / 6,(\mathrm{~L})=\mathrm{Al}-$ Hamdania,$(\mathrm{L} \times \mathrm{C})=\mathrm{Cham} / 6$ in AL-Hamdania,$(\mathrm{L} \times \mathrm{P})=\mathrm{Z}$.T. in AL-Hamdania , $(\mathrm{C} \times \mathrm{P})=\mathrm{Cham} / 6$ in under Chisel,$(\mathrm{L} \times \mathrm{C} \times \mathrm{P})=\mathrm{Cham} / 6$ under Con. Planting method in AL-Hamdania Location.

A-4-Weight of 1000 grains (gm): The best significant result of weight of 1000 grains $(\mathrm{gm})$ in factors and interactions are summarized: $(\mathrm{P})=$ Z.T.,$(\mathrm{C})=\mathrm{Abo}$ Ghariab/3, $(\mathrm{L})=$ Tell Kief,$(\mathrm{L} \times \mathrm{C})=\mathrm{Cham} / 6$ and Abo Ghariab in Tellkief (N.S.).(Note the height value in Tell Affer cultivar ), $(\mathrm{L} \times \mathrm{P})=$ Chisel in Tell Kief , $(\mathrm{C} \times \mathrm{P})=$ Abo Gharib under Z.T. , $(\mathrm{L} \times \mathrm{C} \times \mathrm{P})=\mathrm{Cham} / 6$ under Chisel and Z.T. and Abo Ghariab under Con. Planting method in Tell Kief Location.(Note the height value in Tell affer cultivar under Con. And Z.T.).

A-5-No. of grains /spike: The best significant result of No. of grains/spike in factors and interaction are summarized: $(\mathrm{P})=\mathrm{Z} . \mathrm{T}$. , $(\mathrm{C})=$ Abo Ghariab,$(\mathrm{L})=$ Tell Kief, $(\mathrm{L} \times \mathrm{C})=$ Abo Ghariab in Tell kief,$(\mathrm{L} \times \mathrm{P})=\mathrm{Z}$.T in Tell Kief,$(\mathrm{C} \times \mathrm{P})=\mathrm{Abo}$ Ghariab under Chisel,$(\mathrm{L} \times \mathrm{C} \times \mathrm{P})=$ Abo Ghariab under Chisel in Tellkief location. 
Mesopotamia J. of Agric.

Vol. (42) No.(1) 2014
ISSN: 2224-9796 (Online)

ISSN: $1815-316 \mathrm{X}$ (Print)

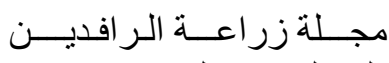
المجلا(42) العدد(1) 2014

Table (1: Effect of planting methods $(\mathrm{P})$ on grains yield $\left(\mathrm{gm} / \mathrm{m}^{2}\right)$ of Bread Wheat cultivars $(\mathrm{C})$.

\begin{tabular}{|c|c|c|c|c|c|}
\hline $\begin{array}{l}\text { Location } \\
\text { (L) }\end{array}$ & (C) (P) & Con. & Chisel & Z.T. & $\begin{array}{c}\mathrm{L} \times \mathrm{C} \\
\text { interaction }\end{array}$ \\
\hline \multirow[t]{2}{*}{ ALHamdania } & cham/6 & $66.45 \mathrm{~h}$ & $55.32 \mathrm{i}$ & $62.92 \mathrm{~h}$ & $61.56 \mathrm{e}$ \\
\hline & Abo Ghariab & $77.76 \mathrm{~g}$ & $77.45 \mathrm{~g}$ & $83.83 \mathrm{fg}$ & $79.68 \mathrm{c}$ \\
\hline \multirow[t]{2}{*}{ Bashyqa } & Cham/6 & $100.15 \mathrm{~cd}$ & $120.75 \mathrm{~b}$ & 88.72 ef & $103.21 \mathrm{~b}$ \\
\hline & Abo Ghariab & $69.18 \mathrm{~h}$ & $68.10 \mathrm{~h}$ & 69.60 & $68.96 \mathrm{~d}$ \\
\hline \multirow[t]{2}{*}{ Tellkief } & Cham/6 & $94.50 \mathrm{de}$ & $150.55 \mathrm{a}$ & $116.13 \mathrm{~b}$ & $120.39 \mathrm{a}$ \\
\hline & Abo Ghariab & $98.26 \mathrm{~d}$ & $106.46 \mathrm{c}$ & $100.80 \mathrm{~cd}$ & $101.84 \mathrm{~b}$ \\
\hline & & & & & (L) \\
\hline \multirow{3}{*}{$\begin{array}{c}\mathrm{L} \times \mathrm{P} \\
\text { Interaction }\end{array}$} & ALHamdania & $72.11 \mathrm{f}$ & $66.39 \mathrm{~g}$ & $73.38 \mathrm{f}$ & $70.63 \mathrm{c}$ \\
\hline & Bashyqa & $84.67 \mathrm{~d}$ & $94.43 \mathrm{c}$ & $79.16 \mathrm{e}$ & $86.09 \mathrm{~b}$ \\
\hline & Tellkief & $96.38 \mathrm{c}$ & $128.51 \mathrm{a}$ & $108.47 \mathrm{~b}$ & $111.12 \mathrm{a}$ \\
\hline & & & & & (C) \\
\hline \multirow{2}{*}{$\begin{array}{c}\mathrm{C} \times \mathrm{P} \\
\text { Interaction }\end{array}$} & Cham/6 & $87.03 \mathrm{bc}$ & $108.87 \mathrm{a}$ & $89.26 \mathrm{~b}$ & $95.05 \mathrm{a}$ \\
\hline & Abo Ghariab & $81.73 \mathrm{~d}$ & $84.00 \mathrm{~cd}$ & $84.74 \mathrm{~cd}$ & $83.49 \mathrm{~b}$ \\
\hline \multicolumn{2}{|c|}{ (P) } & $84.38 \mathrm{c}$ & $96.44 \mathrm{a}$ & $87.0 \mathrm{~b}$ & \\
\hline
\end{tabular}

Table (2): Effect of planting methods (P) on grains yield $\left(\mathrm{gm} / \mathrm{m}^{2}\right)$ of Durum Wheat cultivars (C) .

\begin{tabular}{|c|c|c|c|c|c|}
\hline $\begin{array}{l}\text { Location } \\
\text { (L) }\end{array}$ & (C) (P) & Con. & Chisel & Z.T. & $\begin{array}{c}\mathrm{L} \times \mathrm{C} \\
\text { interaction }\end{array}$ \\
\hline \multirow[t]{2}{*}{ ALHamdania } & OM Rabia & $137.68 \mathrm{f}$ & $102.92 \mathrm{jk}$ & $99.72 \mathrm{k}$ & $113.44 \mathrm{c}$ \\
\hline & Karonia & $117.36 \mathrm{hi}$ & $123.98 \mathrm{~g}$ & $106.55 \mathrm{j}$ & $115.96 \mathrm{c}$ \\
\hline \multirow[t]{2}{*}{ Tellkief } & OM Rabia & $123.46 \mathrm{~g}$ & $166.50 \mathrm{c}$ & $141.80 \mathrm{f}$ & $143.92 \mathrm{~b}$ \\
\hline & Karonia & $148.20 \mathrm{e}$ & $197.55 \mathrm{a}$ & $176.50 \mathrm{~b}$ & $174.08 \mathrm{a}$ \\
\hline \multirow[t]{2}{*}{ Bashyqa } & OM Rabia & $154.82 \mathrm{~d}$ & $157.25 \mathrm{~d}$ & $112.68 \mathrm{i}$ & $141.58 \mathrm{~b}$ \\
\hline & Karonia & $100.43 \mathrm{k}$ & $122.08 \mathrm{gh}$ & 90.731 & $104.41 \mathrm{~d}$ \\
\hline & & & & & $(\mathrm{L})$ \\
\hline \multirow{3}{*}{$\begin{array}{c}\mathrm{L} \times \mathrm{P} \\
\text { Interaction }\end{array}$} & ALHamdania & $127.52 \mathrm{~d}$ & $113.45 \mathrm{e}$ & $103.14 \mathrm{f}$ & $114.70 \mathrm{c}$ \\
\hline & Tellkief & $135.83 \mathrm{c}$ & $182.03 \mathrm{a}$ & $159.15 \mathrm{~b}$ & $159.00 \mathrm{a}$ \\
\hline & Bashyqa & $127.63 \mathrm{~d}$ & $139.67 \mathrm{c}$ & $101.71 \mathrm{f}$ & $123.00 \mathrm{~b}$ \\
\hline & & & & & (C) \\
\hline \multirow{2}{*}{$\begin{array}{c}\mathrm{C} \times \mathrm{P} \\
\text { Interaction }\end{array}$} & OM Rabia & $138.65 \mathrm{c}$ & $142.22 b c$ & $118.07 \mathrm{e}$ & $132.98 \mathrm{a}$ \\
\hline & Karonia & $122.00 \mathrm{de}$ & $147.87 \mathrm{a}$ & $142.59 \mathrm{~d}$ & $131.48 \quad \mathrm{a}$ \\
\hline \multicolumn{2}{|c|}{$(\mathrm{P})$} & $130.325 \mathrm{~b}$ & $145.045 a$ & $121.33 \mathrm{c}$ & \\
\hline
\end{tabular}


Mesopotamia J. of Agric.

Vol. (42) No.(1) 2014
ISSN: 2224-9796 (Online)

ISSN: $1815-316 \mathrm{X}$ (Print)

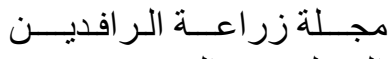
المجلا(42) العدد(1) 2014 العرأن

Table (3): Effect of planting methods $(\mathrm{P})$ on grains yield $\left(\mathrm{gm} / \mathrm{m}^{2}\right)$ of Barley cultivars (C).

\begin{tabular}{|c|c|c|c|c||c|}
\hline $\begin{array}{c}\text { Location } \\
(\mathrm{L})\end{array}$ & $(\mathrm{C})$ & Con. & Chisel & Z.T. & $\begin{array}{c}\text { L x C } \\
\text { interaction }\end{array}$ \\
\hline \multirow{2}{*}{ Hamdania } & Jazzera & $85.05 \mathrm{j}$ & $87.72 \mathrm{j}$ & $75.35 \mathrm{k}$ & $82.70 \mathrm{e}$ \\
\cline { 2 - 6 } & Rihan & $84.22 \mathrm{j}$ & $96.98 \mathrm{i}$ & $76.97 \mathrm{k}$ & $86.05 \mathrm{e}$ \\
\hline \multirow{2}{*}{ Tell Kief } & Jazzera & $192.82 \mathrm{~cd}$ & $194.88 \mathrm{c}$ & $187.62 \mathrm{~d}$ & $191.77 \mathrm{~b}$ \\
\cline { 2 - 6 } & Rihan & $202.12 \mathrm{~b}$ & $209.70 \mathrm{a}$ & $196.96 \mathrm{bc}$ & $202.93 \mathrm{a}$ \\
\hline \multirow{2}{*}{ Bashyqa } & Jazzera & $120.50 \mathrm{~g}$ & $120.40 \mathrm{~g}$ & $109.00 \mathrm{~h}$ & $116.63 \mathrm{~d}$ \\
\cline { 2 - 6 } & Rihan & $102.01 \mathrm{i}$ & $136.08 \mathrm{f}$ & $180.75 \mathrm{e}$ & $139.61 \mathrm{c}$ \\
\hline \multirow{2}{*}{$\begin{array}{c}\text { L x P } \\
\text { Interaction }\end{array}$} & Hamdania & $84.64 \mathrm{~h}$ & $92.35 \mathrm{~g}$ & $76.16 \mathrm{i}$ & $84.38 \mathrm{c}$ \\
\cline { 2 - 6 } & Tellkief & $197.47 \mathrm{~b}$ & $202.29 \mathrm{a}$ & $192.29 \mathrm{c}$ & $197.35 \mathrm{a}$ \\
\hline & Bashyqa & $111.26 \mathrm{f}$ & $128.24 \mathrm{e}$ & $144.88 \mathrm{~d}$ & $128.12 \mathrm{~b}$ \\
\hline
\end{tabular}

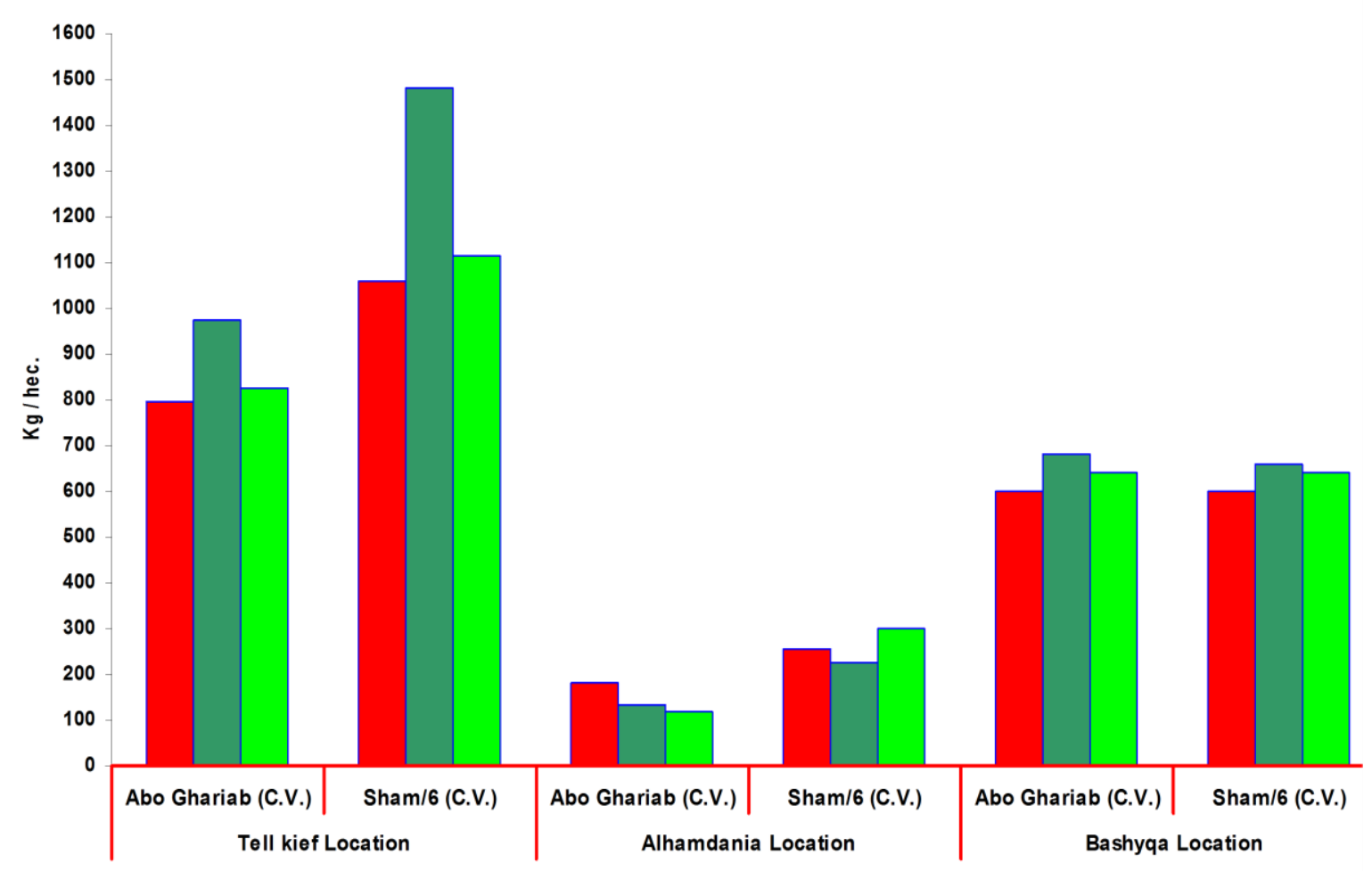

Fig(2): Effect of planting methods on grains ( $\mathrm{Kg} /$ hectar) of bread wheat in MRA location. 
Mesopotamia J. of Agric.

Vol. (42) No.(1) 2014
ISSN: 2224-9796 (Online)

ISSN: 1815-316 X (Print)

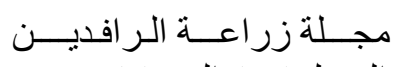

المجلا(42) العدد(1) الرد 2014

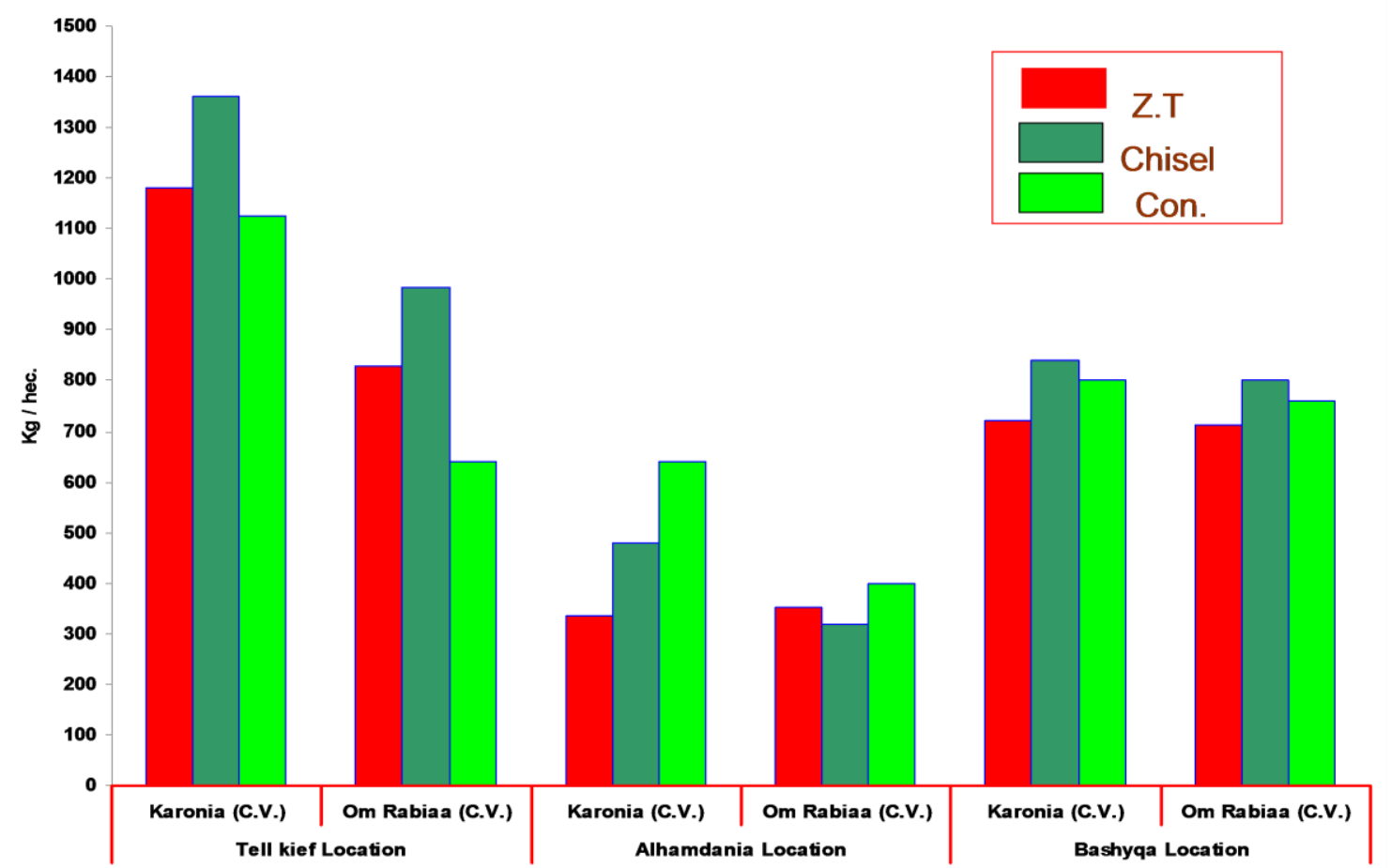

Fig(2): Effect of planting methods on grains ( $\mathrm{Kg} /$ hectar) of Durum wheat in MRA location.

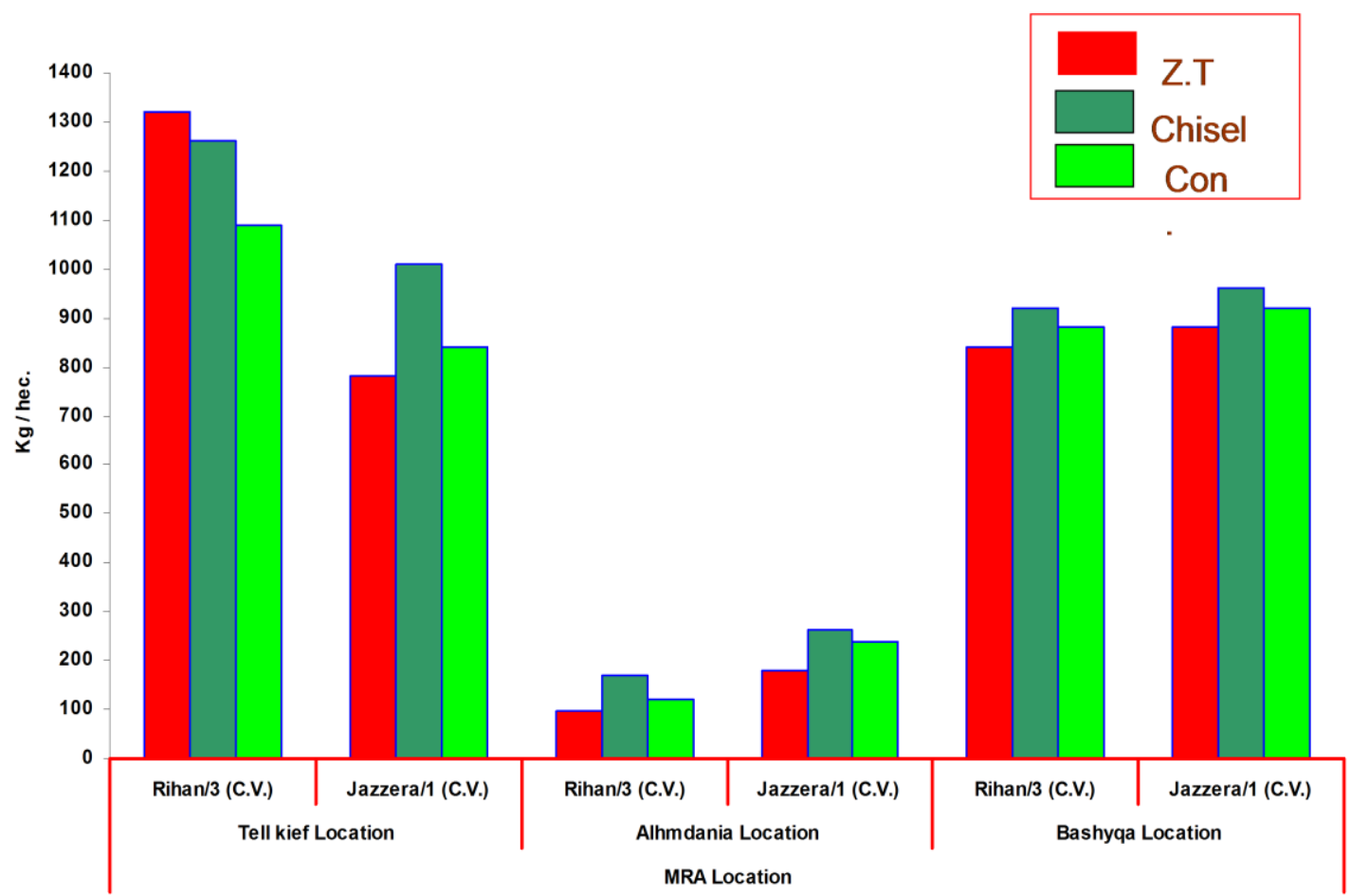

Fig(2): Effect of planting methods on grains ( $\mathrm{Kg}$ / hectar) of Barley in MRA location. 
A-6-Straw Biomass (gm/m2): The best significant result of straw biomass $(\mathrm{gm} / \mathrm{m} 2)$ in factors and interaction are summarized: $(\mathrm{P})=$ Chisel,$(\mathrm{C})=$ Abo Ghariab, $(\mathrm{L})=$ Bashyqa,$(\mathrm{L} \times \mathrm{C})=$ Abo Ghariab in Bashyqa . (Note the height value in Tell Affer cultivar $),(\mathrm{L} \times \mathrm{P})=$ chisel in Bashyqa,$(\mathrm{C} \times \mathrm{P})=$ Abo Ghariab under chisel,$(\mathrm{L} \times \mathrm{C} \times \mathrm{P})=$ Abo Ghariab under chisel and Z.T. in Bashyqa

A-7-Plant height $(\mathbf{c m})$ : The best significant result of plant height $(\mathrm{cm})$ in factors and interaction are summarized: $(\mathrm{P})=$ Z.T.,$(\mathrm{C})=$ Abo Ghariab,$(\mathrm{L})=$ Tell kief , $(\mathrm{L} \times \mathrm{C})=$ Abo Ghariab in Tell kief, $(\mathrm{L} \times \mathrm{P})=\mathrm{Z} . \mathrm{T}$ in Tell kief , $(\mathrm{C} \times \mathrm{P})=$ Abo Ghariab under Z.T. , $(\mathrm{L} \times \mathrm{C} \times \mathrm{P})=$ Abo Ghariab under Z.T in Tellkief location ,

A-8 -Grains Specific weight (Kg/hectoliter):The best significant result of this trait in factors and interaction are summarized : $(\mathrm{P})=$ All planting methods (N.S.), $(\mathrm{C})=$ Cham $/ 6$ and Abo Ghariab (N.S.), $(\mathrm{L})=$ Al Hamdania , $(\mathrm{L} \times \mathrm{C})=$ Abo Ghariab in $\mathrm{Al}$ Hamdania , $(\mathrm{L} \times \mathrm{P})=$ Chisel in $\mathrm{Al}$ Hamdania , $(\mathrm{C} \times \mathrm{P})=\mathrm{Cham} / 6$ under Chisel and Abo Ghariab under Z.T. , $(\mathrm{L} \times \mathrm{C} \times \mathrm{P})=\mathrm{Abo}$ Ghariab under Chisel in Al Hamdania. B-3- No. of Spikes/ $\mathbf{m} 2$ in Durum Wheat :The best significant result of this trait in factors and interactions are summarized $:(\mathrm{P})=$ Chisel,$(\mathrm{C})=\mathrm{OM}$ Rabia,$(\mathrm{L})=\mathrm{AL}$ Ham dania , $(\mathrm{L} \times \mathrm{C})=$ OM Rabia in Al Hamdania , $(\mathrm{L} \times \mathrm{C})=$ Chisel in Al Hamdania , $(\mathrm{C} \times \mathrm{P})=\mathrm{OM}$ Rabia under Chisel , $(\mathrm{L} \times \mathrm{C} \times \mathrm{P})=\mathrm{OM}$ Rabia under Chisel planting method in Al Hamdania location.

B-4-Weight of 1000 Grains (gm):The best significant result of this trait in factors and interactions are summarized : $(\mathrm{P})=$ Control planting method, $(\mathrm{C})=$ Karonia ,

$(\mathrm{L})=$ Tell kief,$(\mathrm{L} \times \mathrm{C})=$ Karonia then OM Rabia in Tell kief , $(\mathrm{L} \times \mathrm{P})=\mathrm{Z} . \mathrm{T}$. and Chisel and con. in Tell kief, $(\mathrm{C} \times \mathrm{P})=$ Karonia under Chisel and OM Rabia under Con $(\mathrm{L} \times \mathrm{C} \times \mathrm{P})=$ Karonia under Z .T . and Chisel and Con in Tell kief location.

B-5-No. of Grains/ Spike :The best significant result of this trait in factors and interactions are summarized : $(\mathrm{P})=\mathrm{Z}$. $\mathrm{T}$. and Chisel,$(\mathrm{C})=$ Karonia,$(\mathrm{L})=$ Tell Kief,$(\mathrm{L} \times \mathrm{C})=$ Karonia in Tell kief,$(\mathrm{L} \times \mathrm{P})=\mathrm{Z} . \mathrm{T}$. in Tell kief,$(\mathrm{C} \times \mathrm{P})=$ Karonia under $\mathrm{Z} . \mathrm{T} .,(\mathrm{L} \times \mathrm{C} \times \mathrm{P})=$ Karonia under $\mathrm{Z} . \mathrm{T}$. in Tell kief .

B-6-Straw Biomass (gm/ m2 ): The best significant result of this trait in factors and interactions are summarized : $(\mathrm{P})=$ Chisel , $(\mathrm{C})=$ Karonia and OM Rabia (N.S.), $(\mathrm{L})=$ Tell Kief,$(\mathrm{L} \times \mathrm{C})=\mathrm{OM}$ Rabia in Al Hamdania and Karonia in Tell kief , $(\mathrm{L} \times \mathrm{P})=$ Chisel in Tell kief,$(\mathrm{C} \times \mathrm{P})=$ Om Rabia under Chisel , $(\mathrm{L} \times \mathrm{C} \times \mathrm{P})=$ Om Rabia under Chisel In Al-Hamadania.

B-7-Plant Height $(\mathbf{c m})$ :The best significant result of this trait in factors and interactions are summarized : $(\mathrm{P})=$ Chisel,$(\mathrm{C})=$ Karonia,$(\mathrm{L})=$ Tell Kief ,

$(\mathrm{L} \times \mathrm{C})=$ Karonia in Tell kief,$(\mathrm{L} \times \mathrm{P})=\mathrm{Z} . \mathrm{T}$. and Chisel in Tell kief ,

$(\mathrm{C} \times \mathrm{P})=$ Karonia under Chisel,$(\mathrm{L} \times \mathrm{C} \times \mathrm{P})=$ Karonia under Chisel in Tell Kief .

B-8-Grains Specific Weight (kg/hectoliter):The best significant result in factors and interactions are summarized : $(\mathrm{P})=$ all planting methods (N.S.) , $(\mathrm{C})=$ Karonia , $(\mathrm{L})=$ Tell Kief,$(\mathrm{L} \times \mathrm{C})=$ Karonia in Tell kief,$(\mathrm{L} \times \mathrm{P})=$ Chisel in Tell kief,$(\mathrm{C} \times \mathrm{P})=$ Karonia under Z .T. , $(\mathrm{L} \times \mathrm{C} \times \mathrm{P})=$ Karonia under all planting methods in Tell Kief .

C-3-No. of Spikes/m2 in Barley:The best significant result of this trait in factors and interactions are summarized: $(\mathrm{P})=$ Chisel, $(\mathrm{C})=$ Jazzera, $(\mathrm{L})=$ Tellkief, $(\mathrm{L} \times \mathrm{C})=$ Jazzera in Tellkief, $(\mathrm{L} \times \mathrm{P})=$ Chisel in Tellkief, $(\mathrm{C} \times \mathrm{P})=$ Jazzera under chisel, $(\mathrm{L} \times \mathrm{C} \times \mathrm{P})=$ Jazzera under Chisel in Tellkief.

C-4-Weight of 1000 Grains (gm):The best significant result of this trait in factors and interactions are summarized : $(\mathrm{P})=$ Chisel,$(\mathrm{C})=$ Rihan,$(\mathrm{L})=$ Tellkief , $(\mathrm{L} \times \mathrm{C})=$ Rihan in Tellkief,$(\mathrm{L} \times \mathrm{P})=$ Chisel in Tellkief,$(\mathrm{C} \times \mathrm{P})=$ Rihan under chisel , 
Mesopotamia J. of Agric.

Vol. (42) No.(1) 2014

$(\mathrm{L} \times \mathrm{C} \times \mathrm{P})=$ Rihan under chisel In Tellkief.

C-5-No. of Grains/spike: The best significant result of this trait in factors and interactions are summarized: $(\mathrm{P})=$ all Planting methods (N.S.), ( C $)=$ Rihan., ( L )= Tellkief., $(\mathrm{L} \times \mathrm{C})=$ Rihan in Tellkief and Bashyqa and Jazzera in Tellkief., $(\mathrm{L} \times \mathrm{P})=$ Z.T. in Tellkief., $(\mathrm{C} \times \mathrm{P})=$ Rihan under Z.T., $(\mathrm{L} \times \mathrm{C} \times \mathrm{P})=$ Rihan under Z.T. In Tellkief. C-6-Straw Biomass $(\mathbf{g m} / \mathbf{m} 2)$ : The best significant result of this trait in factors and interactions are summarized: $(\mathrm{P})=$ Chisel., $(\mathrm{C})=$ Rihan., $(\mathrm{L})=$ Tellkief.,$(\mathrm{L} \times \mathrm{C})=$ Rihan in Tellkief., $(\mathrm{L} \times \mathrm{P})=$ Chisel in Tellkief., $(\mathrm{C} \times \mathrm{P})=$ Rihan under chisel., $(\mathrm{L} \times \mathrm{C} \times \mathrm{P})=$ Rihan under Chisel in Tellkief.

C-7- Plant Height $(\mathbf{c m})$ :The best significant result of this trait in factors and interactions are summarized: $(\mathrm{P})=\mathrm{Z} . \mathrm{T} .,(\mathrm{C}=$ Rihan., $(\mathrm{L})=$ Tellkief., $(\mathrm{L} \times \mathrm{C})=$ Rihan in Tellkief., $(\mathrm{L} \times \mathrm{P})=$ Z.T. in Tellkief., $(\mathrm{C} \times \mathrm{P})=$ Rihan under Z.T., $(\mathrm{L} \times \mathrm{C} \times \mathrm{P})=$ Rihan under Z.T. in Tellkief location.

C-8- Grains Specific Weight (Kg/hectoliter):The best significant result of this trait in factors and interactions are summarized: $(\mathrm{P})=$ Z.T., $(\mathrm{C})=$ Jazzera , $(\mathrm{L})=$ Tellkief,

$(\mathrm{L} \times \mathrm{C})=$ Jazzera in Tellkief, $(\mathrm{L} \times \mathrm{P})=$ all planting methods in Telkief, $(\mathrm{C} \times \mathrm{P})=$ Jazzera under all planting methods. $(\mathrm{L} \times \mathrm{C} \times \mathrm{P})=$ Jazzera under all planting methods in Tellkief. All above results are summarized in table (4).

Table(4) Summary of the effect of planting methods mean on traits mean.

\begin{tabular}{|c|c|c|c|c|}
\hline \multirow[t]{2}{*}{ Traits } & \multicolumn{3}{|c|}{ Crops in MRA locations } & \\
\hline & $\begin{array}{c}\text { MRA Bread } \\
\text { Wheat }\end{array}$ & $\begin{array}{c}\text { MRA Durum } \\
\text { Wheat }\end{array}$ & MRA Barley & \\
\hline $\begin{array}{l}\text { Grain yield } \\
(\mathrm{gm} / \mathrm{m} 2)\end{array}$ & Chisel & Chisel & Chisel & \\
\hline No. spikes/m2 & Chisel & Chisel & Chisel & \\
\hline $\begin{array}{l}\text { Weight of } 1000 \\
\text { grains }(\mathrm{gm})\end{array}$ & Z.T. & Con. & Chisel & \\
\hline No. grains/spike & Z.T. & Z.T.+ Chisel & All & \\
\hline $\begin{array}{l}\text { Straw.biomass } \\
(\mathrm{gm} / \mathrm{m} 2)\end{array}$ & Chisel & Chisel & Chisel & \\
\hline Plant height $(\mathrm{cm})$ & Z.T. & Chisel & Z.T. & \\
\hline $\begin{array}{l}\text { Specific.weight } \\
\text { (kg/hectoliter) }\end{array}$ & All & All & Z.T. & \\
\hline Planting methods & \multicolumn{3}{|c|}{ Superiority repetition in traits } & Total \\
\hline Chisel & 4 & 6 & 5 & 15 \\
\hline Z.T. & 4 & 2 & 3 & 9 \\
\hline Farmer method & 1 & 2 & 1 & 4 \\
\hline
\end{tabular}

The discussion try to determined the cause of superiority of grains yield in any location and any planting methods or any cultivar . It depended on the means value in result table of the three factors:

A- The effect of locations: Telkief location was superior in grain yield of Durum wheat and Bread wheat, and Barley varieties. The cause may be due to the soil texture of Telkief location which was (Clay loam), in comparing with Bashiqa and 
Al Hamdania ( Loam). It means that Telkief soil can retain rain water better than other locations, in the same time the amount of rains was suitable and balanced in the growth season period and it's reached to $(337 \mathrm{~mm})$, Bashiqa received about $(193 \mathrm{~mm})$.In relation to Hamdania location in spite of it was superior in the rate of rain fall which obtained about $(386 \mathrm{~mm})$, but it was faced two environment factors, firstly the amount rainfall was dropped in Febuary .(more than $140 \mathrm{~mm}$ ) when the growth was stopped because of the extreme cold which affect Nineveh during that period. The second factor, exposed location to hot eastern wind during the spike flowering which caused less pollinations.

B-The effect of planting methods: Chisel was superior in this section following by Z.T. and control. It was seamed that Chisel role in deep tillage make soil soft with good root zone and that leads to good roots growth especially with good rains amount which helps this planting method, but ZT still important planting method comparing with conventional tillage ,this result agree with (Farooq et.al,2011), they mentioned from the analysis of 25 experiments that a slight increase in CA crop yields over time relative to CVT, indicating that CA can compete with CVT on a purely crop production basis and also has well-established environmental benefits.

C-The effect of Cultivars: As a general means for the three locations, the cultivar of Bread Wheat (Cham/6) was better than Abu Ghraib, it's due to its number of spikes / $\mathrm{m} 2$ and low of plants height for this cultivar which obtained that the nutritional balance in this cultivar will be for grains yield. In Durum Wheat crop, there were no significant differences between the two variety of wheat (Karonia, Om Rabiaa).

In Barley crop, the variety Rihan / 3 was better than the Jazzera variety. that is due to the superior of Rihan variety in the trait of weight of 1000 grain and No. grains / spike. As a scientific evaluation for the two used planting methods (Z.T and Chisel) in comparing with farmer method, table (4) which explains the effect of the planting methods factor (mean) in which more significant studied traits. The number of traits which was affected by the three planting methods in the crops Bread Wheat, Durum Wheat and Barley were calculated then extracted the most planting methods led to the highest value of the studied traits. Table(4) showed the superiority of the planting method (Z.T.) in a total of (9)traits then corresponds by (Chisel) in a total of ( 15 )traits and lastly the farmer methods planting (Control) in a total of ( 4 )traits ,this results were very encouraged to continue the project with the farmers, with our believe that we need to focus on the new planting method (Z.T) for the next season and we expect that the benefit of it will rise between farmers especially for its lower economic cost because there was no need to cultivation in ZT planting method comparing with other planting methods. The superior results to the Chisel planting method were not correspond with the high costs to use this plow, Although the good preparation for seeds bed by the use of this plow, but its use needs to be pulling by high horsepower tractor (more than 120 horsepower) and this is not available to most farmers in the province especially the poorest of them, another disadvantages by using chisel was the fuel consumption which was too much comparing with ZT planting method and even farmer method, it was known that tillage with chisel need two passes in the field first for plowing and second for sowing seeds, as well as the farmer method, while the ZT planting method need one pass only because there was no plowing in this method, for that fuel consumption in ZT planting method was less by half of both other used methods.This agree with(Hobbs, 2007), he mentioned that tillage costs money in the form of fuel for tractors, wear and tear on 
Mesopotamia J. of Agric.

Vol. (42) No.(1) 2014

equipment, and the cost of the operator .Therefore, the result from use ZT planting method was more efficient in achieving the highest incomes as a result of lack of expenditure used in this method. ZT planting method success in achieving the equation of a difficult economic investigation which is: Reduced inputs leads to maximize outputs (incomes).

\section{ACKNOELEDGMENT}

This study was supported by conservation agriculture project in Ninevah which is under the supervision of Ministry of Agriculture, ICARDA and Mosul Univ. I want to thank Ninevah agriculture Directorate staff whom help me in study implementation .

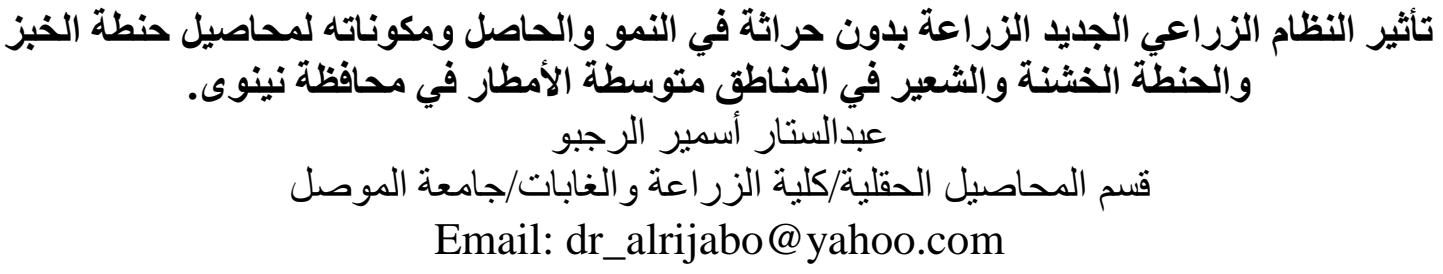

\section{REFRENCES}

Anderson, W. K.; M. A. Hamza; D. L. Sharma; M. F. D`Antuono; F. C. Hoyle; N. Hill; B. J. Shackley; M. Amjad; and C. Zaicou-Kunesch (2005). The role management in yield improvement of the wheat crop-a review with special emphasis on western Australia. Australian Journal of Agriculture Researches. 56: 1137-1149.

Arzhang J. ; H. R. Mohammad; T. Ahmad (2009). Sustainable tillage methods for irrigated wheat production in different regions of Iran. Soil and Tillage Research. 104:143-149.

Engela ,F.L.; I.Bertola; S.R. Rittera; A. Paz Gonzálezb; J. Paz-Ferreirob and E. Vidal Vázquezb(2009). Soil erosion under simulated rainfall in relation to phenological stages of soybeans and tillage methods in Lages, SC, Brazil. Soil and Tillage Research. 103: 216-221. 
Hobbs P. R. (2007). Conservation agriculture : what is it and why is it important for future sustainable food production. Journal of Agricultural Science. 145:127-137.

Kurt S. (2002). Conservation Tillage Gateway to Food Security and Sustainable Rural Development Impact of Conservation Tillage on Soil Quality. Univ. of Zimbabwe.

M. Farooq; K.C. Flower; K. Jabran, A. Wahid; and Kadambot H.M. Siddique (2011). Crop yield and weed management in rainfed conservation agriculture. Soil and Tillage Research. $117: 172-183$.

Mariela F.; G. Bram; De L.Fernando; H.,Luc D. Claudia; D.S. Ken and E. Jorge (2009).Fourteen years of applying zero and conventional tillage, crop rotation and residue management systems and its effect on physical and chemical soil quality. European Journal of Agronomy.30:228-237.

Pettygrove,G.S.;M.J.Smith;T.E.Kearney;L.F.Jackson;W.F.Richareson;P.Livingston; K.Klonsky;S.K.Upadhyaya and W.Bunter (1995).No-Till Wheat and Barley Production in California -California Energy Commission. 1516 Ninth St.,Sacramento,CA 95814.

Ross B.; C.Bill; D.Art; H. John;N. Dave;P.Daya and R. Glem. (1998). No-Till Essentials - Miscellaneous Publication - Australia.52/99-agdex 100/21. 